|Araştırma Makalesi / Research Article |

\title{
Öğretmen Adaylarının Perspektifinden Türk Eğitim Sisteminin Sorunları ve Olası Çözüm Önerileri $^{1}$
}

\section{Problems of the Turkish Education System According to the Prospective Teachers and Their Possible Solutions}

\section{Nilay Neyişci², Tuğba Turabik³ ${ }^{3}$ Feyza Gün ${ }^{4}$ Nuray Kısa ${ }^{5}$}

\author{
Anahtar Kelimeler \\ Türk eğitim sistemi \\ sorunlar \\ öğretmen adayları \\ medya \\ çözüm önerileri
}

\section{Keywords \\ Turkish education system \\ problems \\ prospective teachers \\ media \\ solution suggestions}

Başvuru Tarihi/Received

27.11.2019

Kabul Tarihi /Accepted

05.10.2020
Öz

Bu çalışmanın amacı, öğretmen adaylarının görüşlerine göre medyaya yansıyan haberler üzerinden eğitim sistemimizin sorunlarının ve bu sorunlara yönelik çözüm önerilerinin belirlenmesidir. Nitel araştırma yöntemlerinden durum çalışması ile yürütülen bu çalışma için hazırlanan yarı yapılandırılmış form, 168 öğretmen adayına uygulanmış, 152 öğretmen adayından elde edilen veriler analiz edilmiştir. Veriler, içerik analizi ile çözümlenmiştir. İçerik analizi sonucunda öğretmen adaylarının en çok ifade ettiği soruna ait ana temanın eğitimde şiddet olduğu, bunu sırasıyla eğitim politikaları ile ilgili sorunlar, öğretmenlik mesleği ile ilgili sorunlar, 2023 eğitim vizyonu kapsamında yapılacak değişikliklere yönelik sorunlar, eğitimde fırsat eşitsizliği ile ilgili sorunlar, yükseköğretimle ilgili sorunlar, öğretim programları ile ilgili sorunlar, kişisel tercihlere saygı göstermede yaşanan sorunlar ve diğer sorunların takip ettiği görülmüştür. Öğretmen adayları tarafından en çok ifade edilen çözüm önerilerine ilişkin ana temanın ise eğitim politikalarının geliştirilmesi olduğu ve bunu sırasıyla toplumsal bilinç kazandırılması, istihdam politikalarının geliştirilmesi, eğitim programlarının güncellenmesi, güvenlik, etkili eğitim yönetimi, öğretmen faktörü, aile faktörü ve demokratik eğitimin takip ettiği belirlenmiştir.

\section{Abstract}

The aim of this study is to determine the prospective teachers' opinions about the problems of our education system through the news reflected in the media and their solution proposals for these problems. The semi-structured form pre-pared for this case study, was applied to 168 prospective teachers. The data obtained from 152 prospective teachers were analyzed by content analysis. As a result of the content analysis, it was seen that the main theme of the problem that teacher candidates expressed the most was violence in education; this is followed by problems related to education policies, problems related to the teaching profession, problems related to the changes to be made within the scope of 2023 education vision, problems related to inequality of opportunity in education, problems related to higher education, problems related to curriculums, problems in respecting personal preferences and other problems. It was determined that the main theme of the solution proposals most expressed by the prospective teachers was the development of educational policies, followed by raising social awareness, developing employment policies, updating curriculums, security, effective education management, teacher factor, family factor and democratic education.

\footnotetext{
${ }^{1}$ Bu çalışma 02-04 Mayıs 2019 tarihleri arasında İzmir'de düzenlenen 14. Uluslararası Eğitim Yönetimi Kongresi'nde sunulan sözlü bildirinin geliştirilmiş halidir.

${ }^{2}$ Sorumlu Yazar, Hacettepe Üniversitesi, Eğitim Fakültesi, Eğitim Bilimleri Bölümü, Ankara, Türkiye; https://orcid.org/0000-0002-9360-5337

${ }^{3}$ Hacettepe Üniversitesi, Eğitim Fakültesi; https://orcid.org/0000-0001-9151-9630

${ }^{4}$ Karamanoğlu Mehmetbey Üniversitesi, Eğitim Fakültesi, Eğitim Bilimleri Bölümü, Karaman,Türkiye; https://orcid.org/0000-0001-8395-2020

${ }^{5}$ Niğde Ömer Halisdemir Üniversitesi, Eğitim Fakültesi, Eğitim Bilimleri Bölümü, Niğde, Türkiye; https://orcid.org/0000-0002-6085-4329
}

Alıntı/Citation: Neyişci, N., Turabik, T., Gün, F., \& Kısa, N. (2020). Öğretmen adaylarının perspektifinden Türk eğitim sisteminin sorunları ve olası çözüm önerileri. Kastamonu Education Journal, 28(6), 2257-2270. doi: 10.24106/kefdergi.4095 


\section{Extended Abstract}

\section{Introduction}

One of the most important factors determining countries' development levels is education. Qualified education affects the economic, political and cultural development of countries with its externalities at the social level. Quality indicators of education systems include access, equality and fairness, grade retention and dropout rates, standards, academic achievement, teachers and teaching, assessment, finance, management, family-society and the environment (Tokuhama-Espinosa et al. 2013). According to literature there are problems in our education system in terms of these indicators (Arslan, 2004; Gedikoğlu, 2005; Inan and Bekler, 2014; Korkmaz, 2005; Özdemir and Kaplan, 2017; Uluğ, 1998; Üstüner, 2004; Yılmaz and Altınkurt, 2011). In these studies, the highlighted problems were schooling rates, problems related to vocational-technical education, education-employment balance, the number of students per teacher, inter-regional educational inequalities, social justice in education, inequality of opportunities, and the quality of human resources. In some studies, problems of our education system were determined from the perspectives of teacher candidates (Abu, Bacanak and Gökdere, 2016; Özdemir and Kaplan, 2017; Yeşil and Şahan, 2015; Yılmaz and Altınkurt, 2011). In this context, it is observed that teacher candidates mostly emphasize the constantly changing education system, rote learning, lack of infrastructure, teacher training and education problems, ideological approaches, examination system, crowded classes, parental participation and professional orientation problems. Examining the perspectives of the candidate teachers about the problems and the solutions is important in terms of giving an idea about how our future education system will be shaped. Aim of this study is to determine the opinions of prospective teachers about the problems of the education system and possible solution suggestions through the news reflected in the media.

\section{Method}

In this research case study is used which is one of the qualitative research models, because describing the problems of the Turkish education system based on the opinions of prospective teachers according to the news reflected to media and developing possible solutions for the existing problem are aimed. The study group consisted of 168 prospective teachers in the fall semester of the 2017-2018 academic year in the Faculty of Education of a public university in Ankara. The study was conducted on 152 data that are suitable for the analysis. As the data collection tool, the researchers developed a semi-constructed form and performed validity and reliability studies. First part of the form consists of information about the gender and the department of participants. In the second part, there are two questions related with the aim of the research. The questions are: When you think about the current news about the problems or developments in education; (a) Explain why you see this news as a problem. (b) Explain any possible suggestions (solution, development, improvement, renewal, etc.) about the topic. The data were analyzed by content analysis. The situations which are perceived by prospective teachers as a problem through the news reflected in the media and the solutions to these problems are presented with frequency and percentage values for main themes and sub themes.

\section{Result}

The main themes according to prospective teachers about problems are as follows: Violence $(f=54)$, problems related to educational policies $(f=29)$, problems related to the teaching profession $(f=15)$, problems related to the changes to be made within the scope of 2023 education vision $(f=12)$, problems related to inequality of opportunity in education ( $f=10)$, problems related to curriculum $(f=10)$, problems related to higher education $(f=9)$, problems in respecting personal preferences $(f=7)$ and other problems $(f=6)$. In this regard, the most important problems that prospective teachers focus on are violence in education, education policies and problems related to teaching profession.

The main themes of prospective teachers' possible solutions to these problems are as follows: Developing education policies $(f=81)$, raising social awareness $(f=36)$, improving employment policies $(f=35)$, developing curriculum $(f=31)$, security $(f=29)$, effective education management $(f=26)$, teacher factor $(f=8)$, family factor $(f=7)$ and democratic education $(f=4)$. In the main themes related to the possible solution proposals of the prospective teachers, it is seen that the solution proposals for the development of education policies, raising social awareness and improving employment policies are prominent.

\section{Discussion}

When similar studies in the literature are examined, it is seen that violence is an important problem in our education system and individuals are frequently exposed to violence in the system (Erdemli, 2018; Gündüz, 2015). When the studies related to the problems in the education policies, which follows the violence theme are examined, similar with the current study, it is seen that there are studies, revealing that teachers and prospective teachers think that there are problems in education policies (Çetin, Yazar, Aydın and Yazıcı, 2018; Kartal, 2013; Özdemir and Kaplan 2017). Problems related to the teaching profession appear as a subject that has been emphasized in many studies and that teacher candidates are frequently mentioned. The problems related to the teaching profession appear as a subject that has been emphasized in many studies and that teacher candidates are frequently mentioned (Çetin et. al, 2018; Gedikoğlu, 2005; Hareket, Erdoğan and Dündar, 2016; Kartal, 2013; Özdemir and Kaplan, 2017; Şener, 2018; Taşdemir, 2015; Yılmaz and Altınkurt, 2011). When the studies discussing the solution proposals for the problems of the Turkish education system are examined, it is seen that both the teacher candidates and the researchers offer similar solutions to the results obtained in this study (Arslan, 2004; Gedikoğlu, 2005; Özdemir and Kaplan, 2017; Uluğ, 1998; Yeşil and Şahan, 2015; Yıldırım and Yıldızhan, 2016). 


\section{Pedagogical Implications}

In this research, prospective teachers were informed by analyzing the problems of our education system through the news in the media and they were encouraged to develop solutions for these problems. This might be a step to prepare them for the challenges they will face when they start their professional careers as teachers in the future and setting out appropriate action plans to overcome such problems and/or deficiencies.

\section{Giriş}

Ülkelerin kalkınmışlık seviyesini belirleyen en önemli faktörlerden birisi eğitimdir. Eğitim, bireysel yararlarının yanı sıra, toplumsal düzeyde sağladığı faydalar ile de ülkelerin ekonomik, siyasal ve kültürel bakımdan kalkınmalarında etkili olmaktadır. Bireylerin eğitim düzeyi yükseldikçe ekonomi ve ona dayalı piyasalar iyileşmeye başlarken, demokrasi tüm kurum ve kurallarıyla daha iyi işleyebilmekte, teknolojik değişimlere uyum sağlamak kolaylaşmakta, toplumdaki suç işleme oranları ile iç güvenlik ve adalet hizmetlerine yapılan harcamalar azalmakta, kişilerin gelirleri artmakta ve gelir adil dağıtılmakta, insanlar sağlıklarının korunmasında daha bilinçli davranmakta, toplumsal yardıma muhtaç kişi sayısı da azalmaktadır (Öztürk, 2005). Eğitimin tüm bu işlevlerinin yerine getirilmesi ancak kaliteli eğitim sistemleri ile mümkün olabilir. Bu görüşe paralel şekilde Hanushek ve Wößmann (2007) kaliteli eğitim ile kalkınmışlık arasında doğrudan bir bağlantı olduğunu savunmuşlardır. UNICEF (2000)'e göre eğitimde kalite, ailesi ve çevresi tarafından desteklenen, öğretim sürecine katılmaya hazır sağlıklı bireyleri; güvenilir, koruyucu, cinsiyet eşitliğini benimseyen, hem fiziksel hem de psikososyal bağlamda yeterli imkân ve olanakların sağlandığı çevreyi; akademik bilginin yanında günlük yaşam dinamiklerine ayak uydurma becerisini bireylere kazandıracak program ve materyal desteğini sunan içeriği; öğrenci merkezli öğretim yaklaşımını benimseyen iyi yetişmiş öğretmenlerin olduğu, adil bir değerlendirme sistemine sahip, iyi yönetilen okullardaki süreci ve ulusal eğitim sisteminin amaçları doğrultusunda bireye kazandırılmış bilgi, beceri ve tutumu kapsayan çıktıyı içermektedir. Tokuhama-Espinosa ve arkadaşları (2013) ise eğitim sistemlerinin kalite göstergelerini on bir ana başlıkta olmak üzere "erişim, eşitlik ve adalet, sınıf tekrarı ve okulu bitirme oranları, standartlar, akademik başarı, öğretmenler ve öğretim, ölçme ve değerlendirme, finans, yönetim, aile-toplum ve çevresel bağlam" şeklinde ele almışlardır. Alanyazında, Türk eğitim sisteminde bu göstergeler bakımından bazı sorunlar olduğunu ortaya koyan çalışmalar bulunmaktadır (Aktepe, 2014; Arslan, 2004; Gedikoğlu, 2005; Genç ve Eryaman, 2008; Güngör ve Göksu, 2013; İnan ve Bekler, 2014; Korkmaz, 2005; Memduhoğlu, 2007; Özdemir ve Kaplan, 2017; Seyfullahoğulları, 2010; Uluğ, 1998; Üstüner, 2004; Yılmaz ve Altınkurt, 2011). Bu çalışmalarda okullaşma oranları, mesleki teknik eğitim uygulamaları, eğitim ve istihdam dengesi, öğretmen başına düşen öğrenci sayısı, bölgeler arası eğitimsel eşitsizlikler, eğitimde sosyal adalet, fırsat ve imkân eşitsizliği, eğitimin finansmanı ve insan kaynaklarının ve eğitim programlarının niteliği gibi sorun başlıklarının ortaya çıktığı görülmektedir. Türkiye'de 1960'lardan itibaren uygulamaya konan kalkınma planları ile birlikte başlayan planlı dönemde eğitim politikalarının insan gücü kaynağının geliştirilmesi, sosyal ve coğrafi engellerin ortadan kaldırılması olmak üzere iki ana sorun üzerine odaklandığı görülse de (Aytaç, 1967) ilerleyen yıllarda toplumsal koşullara bağlı olarak sorunların çeşitlenerek arttığı görülmektedir.

Bazı araştırmalarda ise Türk eğitim sisteminin sorunları öğretmen adayları özelinde ele alınmıştır (Kutlu-Abu, Bacanak ve Gökdere, 2016; Özdemir ve Kaplan, 2017; Yeşil ve Şahan, 2015; Yılmaz ve Altınkurt, 2011). Yılmaz ve Altınkurt (2011) eğitim sisteminin sorunlarını inceleyen çok çeşitli araştırma bulguları olduğunu vurgulamakla birlikte bu konuda öğretmen adaylarının görüşlerini inceleyen az sayıda araştırmanın olduğunu ifade etmiş ve öğretmen adaylarının sistemin gelecekteki uygulamacıları olarak görüşlerinin alınmasının sistemdeki sorunlara ilişkin önemli ipuçları sunacağını belirtmiştir. Bu bağlamda öğretmen adaylarının en çok sürekli değişen eğitim sistemi, ezbere dayalı eğitim, altyapı eksikliği, öğretmenlerin yetiştirilmesi ve öğretmen niteliksizliği, ideolojik yaklaşımlar, sınav sistemi, kalabalık sınıflar, veli katılımı ve mesleki yönlendirme ile ilgili sorunları vurguladıkları göze çarpmaktadır. Tüm bunların yanında Türk eğitim sisteminin yapısal olarak kendi sorunları ile mücadele etmesinin henüz mümkün olmadı̆̆ını ve bu yapının pek çok farklı siyasal, ekonomik, sosyal sorunlara da kaynak teşkil ettiğini belirten çalışmalar da mevcuttur (Güngör ve Göksu, 2013; Taşdelen, 2012; Taşgın ve Sönmez, 2013).

Milli Eğitim İstatistikleri'ne göre 2017-2018 öğretim yılında Türkiye'de 686 bin 800 derslikte, toplam 7 milyon 885 bin 248 öğrenci eğitimden yararlanırken, örgün eğitim kurumlarında 1 milyon 30 bin 130 öğretmen görev yapmaktadır (MEB, 2018). Tüm bu istatistiksel veriler değerlendirildiğinde Türk eğitim sisteminin kapsamının ne kadar geniş olduğu ve bu kapsam da sorunların da çeşitlilik gösterdiği söylenebilir. Eğitimin amaçlarının gerçekleşebilmesi ve temel işlevlerinin yerine getirilmesi eğitim sisteminde yaşanan sorun ve eksikliklerin giderilmesiyle mümkün olacaktır. Çünkü eğitimin herhangi bir kademesindeki bir sorun ve bu soruna yönelik değişiklikler tüm sistemi etkileyecektir. Bu bağlamda, örgün eğitimin son basamağında olan lisans öğrencilerinden eğitim sistemindeki sorunlardan doğrudan ya da dolaylı olarak etkilenen kişiler olarak görüş ve önerilerinin alınması, sistemle ilgili yapılacak değerlendirmelerde ve sisteme yönelik çözüm önerilerinin geliştirilmesinde önemli bulgular sunabilir. illerleyen süreçlerde sistemde aktif rol alacak bireyler olarak öğretmen adaylarının bu sorunlara yönelik çözüm önerileri geliştirmeleri sistemin iyileştirilmesine katkı sağlayacak bir adım olarak düşünülebilir. Eğitim sisteminde kilit role sahip öğretmenlerin yetişme sürecinde eğitim sorunlarına ilişkin bakış açılarının ve bu sorunlara yönelik geliştirecekleri çözüm önerilerinin incelenmesi gelecekteki eğitim sistemimizin nasıl şekilleneceği konusunda fikir vermesi açısından da önemli görülmektedir. Bu çalışma öğretmen adaylarının görüşlerine dayalı olarak, onların içinde bulundukları eğitim sistemindeki sorunlara karşı ne kadar duyarlı olduklarına dair ipuçları sağlayarak, Türk eğitim sistemine ilişkin nasıl bir tutuma sahip olduklarını ortaya koyacaktır.

Bu çalışmada öğretmen adaylarının Türk eğitim sisteminde sorun olarak gördükleri durumların belirlenmesi ve bu sorunlara ne tür çözümler geliştirebileceklerinin ortaya konulması amaçlanmıştır. Bu amaç çerçevesinde Türk eğitim sisteminde yer alan 
sorunlar medyaya yansıyan haberler üzerinden öğretmen adaylarının görüşlerine dayalı olarak ayrıntılı bir şekilde tanımlanmış, var olan soruna ilişkin olası çözüm önerileri geliştirilmiş ve sonuçta bu haberler Türk eğitim sisteminin sorunları bağlamında değerlendirilmeye çalışılmıştır. Yapılan haberler ve bu haberlere yapılan yorumlar aracılığıyla mevcut toplumsal yargıları etkileyebilme ya da yeniden üretebilme gücüne sahip olan medya (Görgün-Baran, Sarıtaş ve Şahin-Kütük, 2017) toplumda bir kamuoyunun oluşmasına ve insanların yoğun bir yönlendirme ile karşı karşıya kalmasına neden olabilir. Medyanın bireylerin inanç, tutum ve davranışlarında değişmelere sebep olabileceği düşünüldüğünde, medyada eğitim sistemine yönelik sorunların nasıl ele alındığı ve bu sorunların ele alınış biçimlerinin ya da verdiği mesajların öğretmen adaylarının görüşlerine yansımalarının nasıl olduğunun tespit edilmesi eğitim sistemindeki sorunları belirlemeye yönelik farklı bir perspektif sunabilir. Buradan hareketle bu çalışmada şu sorulara cevaplar aranmıştır.

1. Eğitimle ilgili güncel haberlere dayalı olarak aday öğretmenlerin eğitim sisteminde sorun olarak gördükleri durumlar nelerdir?

2. Aday öğretmenlerin bu sorunlara ilişkin çözüm önerileri nelerdir?

\section{YÖNTEM}

Bu çalışmada Türk eğitim sisteminde yer alan sorunların medyaya yansıyan haberler üzerinden öğretmen adaylarının görüşlerine dayalı olarak ayrıntılı bir şekilde tanımlanması, var olan soruna ilişkin olası çözüm önerilerinin geliştirilmesi amaçladığından nitel araştırma modellerinden biri olan durum çalışması modeli kullanılmıştır. Durum çalışması Davey’e (2009) göre, bir ya da daha fazla durum veya olayın derinlemesine incelenerek, sistematik olarak elde edilen verilerden hareketle gerçek durumlar içerisinde neler olduğuna odaklanan bir yöntemdir. Durum çalışmalarında incelenen olgu, durum ya da sorun ile içinde bulunduğu ortam arasında kesin sınırların çizilemediği ve veri kaynaklarının fazla olduğu söylenebilir (Yıldırım ve Şimşek, 2005; Yin, 1984).

\section{Çalışma Grubu}

$\mathrm{Bu}$ araştırmanın çalışma grubu belirlenirken araştırmacının alışkın olduğu bir grupla, daha az maliyetle çalışmasına olanak sağlayan ve araştırmacıya hız ve pratiklik kazandıran (Yıldırım ve Şimşek, 2005) amaçlı örnekleme yöntemlerinden biri olan "kolay ulaşılabilir örnekleme" tekniği kullanılmıştır. Araştırmanın çalışma grubunu Ankara'da bulunan bir devlet üniversitesinin Eğitim Fakültesi'nde 2017-2018 akademik yılı güz döneminde öğrenim gören 168 öğretmen adayı oluşturmaktadır. Analize uygun olan 152 veri üzerinden çalışma yürütülmüştür. Araştırmanın çalışma grubuna dâhil edilen öğretmen adaylarının özellikleri Tablo 1'de sunulmaktadır.

Tablo 1. Öğretmen adaylarının özellikleri

\begin{tabular}{|c|c|c|c|}
\hline Değişkenler & Alt Gruplar & $\mathrm{N}$ & $\%$ \\
\hline \multirow{2}{*}{ Cinsiyet } & Kadın & 115 & 75 \\
\hline & Erkek & 37 & 25 \\
\hline \multirow{6}{*}{ Bölüm } & İngiliz Dili Eğitimi & 85 & 55 \\
\hline & Fen Bilgisi Eğitimi & 19 & 13 \\
\hline & Rehberlik ve Psikolojik Danışmanlık & 15 & 10 \\
\hline & Fransız Dili Eğitimi & 13 & 9 \\
\hline & İlköğretim Matematik Öğretmenliği & 12 & 8 \\
\hline & Okul Öncesi Eğitimi & 8 & 5 \\
\hline Toplam & & 152 & 100 \\
\hline
\end{tabular}

Tablo 1'e göre araştırmaya katılan öğretmen adaylarının 115'inin (\%75) kadın ve 37'sinin erkek (\%25) olduğu görülmektedir. Katılımcılar sırasıyla İngiliz Dili Eğitimi (\%55), Fen Bilgisi Eğitimi (\%13), Rehberlik ve Psikolojik Danışmanlık (\%10), Fransız Dili Eğitimi (\%9), ilköğretim Matematik Öğretmenliği (\%8) ve Okul Öncesi Eğitimi (\%5) bölümlerinde öğrenim görmektedirler.

\section{Veri Toplama Aracı ve Süreci}

Veri toplama aracı olarak; katılımcıların medyadaki haberlerde karşılaştıkları ve eğitim sistemini ilgilendiren bir sorun olduğunu düşündükleri bir durumu tanımlamalarını ve bu duruma ilişkin olası çözüm önerilerini ortaya çıkarmalarını amaçlayan iki sorudan oluşan, yarı yapılandırılmış bir form kullanılmıştır. Veri toplama formu oluşturulmadan önce, alanyazın taraması sonucu oluşturulan olası maddeler araştırmacılar tarafından incelenmiş ve bu maddeler Hacettepe Üniversitesi Eğitim Fakültesi'nde görev yapan üç alan uzmanının görüşlerine sunulmuştur. Elde edilen görüş ve öneriler sonrasında araştırmacıların fikir birliği de sağlanarak veri toplama formuna nihai şekli verilmiştir.

Veri toplama formunun ilk bölümünde katılımcıların cinsiyetleri ve eğitim aldıkları bölüme ilişkin bilgiler yer almaktadır. İkinci bölümde ise, araştırmanın amacını yansıtacak şekilde hazırlanmış iki soru bulunmaktadır. Bu sorular şu şekildedir: Eğitimde yaşanan sorunlar veya gelişmeler ile ilgili güncel haberleri düşündüğünüzde; (a) Aklınıza gelen/karşılaştığınız bu haberi neden sorun olarak gördüğünüzü açıklayınız. (b) Konu ile ilgili olası önerilerinizi (çözümü, geliştirilmesi, iyileştirilmesi, yenilenmesi vs.) açıklayınız. 
Çalışmaya gönüllü olarak katılmayı kabul edenlere veri toplama sürecinden önce araştırma hakkında bilgi verilmiştir. Daha sonra yarı yapılandırılmış veri toplama formları dağıtılarak, katılımcıların formdaki maddelere ilişkin görüşlerini yazılı olarak belirtmeleri talep edilmiştir. Uygulama yaklaşık olarak yirmi dakika kadar sürmüştür. Uygulama sonrasında katılımcılardan doldurdukları formları tekrar okumaları istenerek, veri toplama formundaki ifadelerini teyit etmeleri istenmiştir.

\section{Verilerin Analizi}

Toplanan formlar incelendiğinde, eksik bilgi verilen ve cevapların amaca yönelik veri sağlamadığı durumlarda veri analize dâhil edilmemiştir. Sonuç olarak araştırmaya katılan 168 öğretmen adayının 152'sinden elde edilen veri, analiz edilmiştir. Verilerin çözümlenmesinde içerik analizi tekniği kullanılmıştır. Katılımcı formlarından elde edilen veriler, kod isimler kullanılarak bilgisayar ortamına aktarılmıştır. İçerik analizinin temelinde, elde edilen verileri tanımlayacak ve açıklayabilecek kavramlara ulaşmak hedeflenmektedir. Bu amaçla, verilerin kodlanarak kavramsallaştırılması, daha sonra bu kodlar arasındaki ilişkilerin belirlenerek temaların oluşturulması ve son olarak elde edilen bulguların yorumlanması aşamaları takip edilmiştir (Yıldırım ve Şimşek, 2005). Tema ve alt temaların oluşturulması aşamaları araştırmacılar tarafından birbirinden bağımsı olarak gerçekleştirilmiştir. Araştırmacılar tarafından bağımsız üretilen kod ve temalar karşılaştırılmış ve ortak kod ve temalar üzerinde uzlaşılmıştır.

Lincoln ve Guba (1985), nitel araştırmalarda elde edilen verilerin geçerliğini ve güvenirliğini değerlendirmek için 4 kriter belirlemiştir. Bu kriterler; İnandırıcılık-credibility (iç geçerlik), aktarılabilirlik-transferability (dış geçerlik), güvenilebilirlikdependability (iç güvenirlik), ve onaylanabilirlik-confirmability (objektiflik) olarak ifade edilmiştir (Akt. Shenton, 2004). Bu kapsamda araştırmanın geçerliği ve güvenirliği için bazı aşamaların gerçekleştirilmesi önemli görülmektedir.

Araştırmanın inandırıcılığını diğer bir ifade ile iç geçerliği sağlamak için "Sonuçlar inandırıcı mı?" sorusundan hareketle bazı yöntemlere başvurulmuştur. Bunlardan ilki uzun süreli etkileşim olarak ifade edilen araştırmacının verinin toplanacağı ortamda bulunması, veri toplamak için yeterli zamanın ayrılması ve böylece katılımcıların görüşlerini anlayabilmesi için derinlemesine gözlem yapmasıdır. Böylece karşılıklı güvene dayalı bir ilişki kurulacak, doğru bilgiler alınabilecektir (Houser, 2015). İç geçerliği artırmak için ayrıca veri toplama aracının geliştirilmesi sürecinde uzman görüşüne başvurulmuş, bulgular doğrudan alıntılarla desteklenmiş ve veri toplama aracı ile bulguların alan yazınla tutarlılığı sağlanmıştır (Yurdakul, 2008).

Araştırmanın aktarılabilirliğini, diğer bir ifade ile dış geçerliği sağlamak için "Sonuçlar diğer kişi ve durumlara aktarılabilir mi?" sorusundan hareketle bazı yöntemlere başvurulmuştur. Bunun için katılımcıların nasıl belirlendiğine ilişkin örnekleme yöntemi, katılımcı özellikleri ve veri toplama süreciyle ilgili bilgiler açık ve net bir şekilde belirtilmiş, araştırmanın tüm süreçleri ayrıntılı bir şekilde betimlenmeye çalışılmıştır (Sharts-Hopko, 2002).

Araştırmanın güvenilebilirliğini diğer bir ifade ile iç güvenirliğini sağlamak için "Çalışma benzer koşullarda benzer katılımcılarla tekrarlandığında sonuçlar benzer mi?" sorusundan hareketle bazı yöntemlere başvurulmuştur. Çalışma kapsamında oluşturulan tema ve alt temalar her bir araştırmacı tarafından ayrı ayrı yapılmış daha sonra kodlamalar arasında uyuşum yüzdesine bakılmıştır. Kodlamalar arasındaki uyuşum yüzdesi Güvenirlik = Görüş Birliği Sayısı / (Toplam Görüş Birliği + Görüş Ayrılığı Sayısı) formülü ile hesaplanmış ve kod uyuşum yüzdesi \%96 olarak bulunmuştur. Uyuşum yüzdesinin \%70'in üzerinde hesaplanması dolayısıla kodlama aşamasının güvenilir olduğuna karar verilmiştir (Miles ve Huberman, 1994).

Araştırmanın onaylanabilirliğini diğer bir ifade ile objektifliğini sağlamak için “Önyargılar azaltılarak objektiflik artırıldı mı?” sorusundan hareketle bazı yöntemlere başvurulmuştur. Araştırmanın bulguları araştırmacıların önyargıları ya da görüşleri yerine katılımcıların kendi ifadelerinden hareketle sunulmuş, katılımcı görüşleri doğrudan alıntılarla desteklenmiştir.

\section{BULGULAR}

\section{Türk Eğitim Sisteminin Sorunlarına ilişkin Bulgular}

Katılımcı öğretmen adaylarının eğitimde yaşanan sorunlar veya gelişmeler ile ilgili güncel haberleri düşündüklerinde bu haberi neden bir sorun olarak gördüklerine dair yöneltilen soruya ilişkin özellikle, şiddet, eğitim politikaları ile ilgili sorunlar, öğretmenlik mesleği ile ilgili sorunlar, 2023 Eğitim Vizyonu kapsamında yapılacak değişikliklere yönelik sorunlar gibi konu başlıklarına yönelik görüşler belirttikleri gözlenmiştir. Tablo 2'de bu bulguya ilişkin veriler sunulmaktadır. 
Tablo 2. Öğretmen adaylarının görüşlerine göre Türk eğitim sisteminin sorunları

\begin{tabular}{|c|c|c|c|c|c|}
\hline Tema & $f$ & $\%$ & Alt Temalar & $f$ & $\%$ \\
\hline \multirow{4}{*}{ Şiddet } & \multirow{4}{*}{54} & \multirow{4}{*}{35.5} & Öğretmene şiddet & 34 & 62.96 \\
\hline & & & Eğitim paydaşları arasındaki şiddet & 11 & 20.37 \\
\hline & & & Öğrenciye şiddet & 7 & 12.96 \\
\hline & & & Öğrenciler arasındaki şiddet & 2 & 3.71 \\
\hline \multirow{11}{*}{$\begin{array}{l}\text { Eğitim politikaları ile ilgili } \\
\text { sorunlar }\end{array}$} & \multirow{11}{*}{29} & \multirow{11}{*}{19.0} & Üst kademeye geçiş sınavları ile ilgili sorunlar & 7 & 24.13 \\
\hline & & & Yanlış eğitim politikaları & 4 & 13.79 \\
\hline & & & Mesleki ve teknik eğitimdeki sorunlar & 3 & 10.34 \\
\hline & & & Okul öncesi eğitimin zorunlu olmaması & 2 & 6.90 \\
\hline & & & Türk eğitim sisteminin gelişimindeki eksiklik & 2 & 6.90 \\
\hline & & & Eğitim finansmanındaki sorunlar & 2 & 6.90 \\
\hline & & & Liselere sınavsız geçiş & 2 & 6.90 \\
\hline & & & Ortaöğretim sisteminin yenilenmesi & 2 & 6.90 \\
\hline & & & Özel okul sayısındaki artış & 2 & 6.90 \\
\hline & & & İkili öğretimin sona ermesi & 2 & 6.90 \\
\hline & & & Okullarda rehberlik hizmetlerine önem verilmemesi & 1 & 3.44 \\
\hline \multirow{3}{*}{$\begin{array}{l}\text { Öğretmenlik mesleği ile ilgili } \\
\text { sorunlar }\end{array}$} & \multirow{3}{*}{15} & \multirow{3}{*}{9.8} & Öğretmen yetiştirme ve atama sürecindeki sorunlar & 8 & 53.34 \\
\hline & & & Öğretmenlik mesleğinin itibarının azalması & 5 & 33.33 \\
\hline & & & Öğretmenlerin doğuda görev yapmaktan kaçınması & 2 & 13.33 \\
\hline \multirow{4}{*}{$\begin{array}{l}2023 \text { Eğitim Vizyonu kapsamında } \\
\text { yapılacak değişikliklere } \\
\text { yönelik sorunlar }\end{array}$} & \multirow{4}{*}{12} & \multirow{4}{*}{7.9} & 40 dakika ders, 40 dakika teneffüs uygulaması & 6 & 50 \\
\hline & & & Gözetimsiz sınav önerisi & 3 & 25 \\
\hline & & & Okul öncesi döneme yönelik yaz okulu eğitimleri & 2 & 16.66 \\
\hline & & & Özel öğretime teşviklerin kademeli olarak kaldırılması & 1 & 8.34 \\
\hline \multirow{4}{*}{$\begin{array}{l}\text { Eğitimde fırsat eşitsizliği ile ilgili } \\
\text { sorunlar }\end{array}$} & \multirow{4}{*}{10} & \multirow{4}{*}{6.5} & Eğitimde cinsiyetçi yaklaşımlar & 4 & 40 \\
\hline & & & Göçmenlerin eğitimi & 3 & 30 \\
\hline & & & Engelli öğrencilerin eğitiminde yaşanan sorunlar & 2 & 20 \\
\hline & & & Okullar arası başarı farkları & 1 & 10 \\
\hline \multirow{7}{*}{$\begin{array}{l}\text { Öğretim programları ile ilgili } \\
\text { sorunlar }\end{array}$} & \multirow{7}{*}{10} & \multirow{7}{*}{6.5} & Müfredattaki eksikler & 2 & 20 \\
\hline & & & Yabancı dil eğitiminde yaşanan sorunlar & 2 & 20 \\
\hline & & & Uzaktan eğitim programındaki sorunlar & 2 & 20 \\
\hline & & & Kodlama eğitimine önem verilmemesi & 1 & 10 \\
\hline & & & Girişimcilik programlarındaki eksiklikler & 1 & 10 \\
\hline & & & İş sağıı̆̆ı güvenliğinin programda olmaması & 1 & 10 \\
\hline & & & Öğretim programlarının öğrencilerin ilgi ve yeteneklerine yönelik olmaması & 1 & 10 \\
\hline \multirow{5}{*}{ Yükseköğretimle ilgili sorunlar } & \multirow{5}{*}{9} & \multirow{5}{*}{5.9} & Okul terki & 3 & 33.33 \\
\hline & & & Üniversite öğrencilerinin kariyer sorunu & 3 & 33.33 \\
\hline & & & Niteliksiz eğitim & 1 & 11.11 \\
\hline & & & Lisansüstü eğitimde yaşanan sorunlar & 1 & 11.11 \\
\hline & & & İşsizlik korkusu & 1 & 11.11 \\
\hline \multirow{2}{*}{$\begin{array}{l}\text { Kişisel tercihlere saygı } \\
\text { göstermede yaşanan sorunlar }\end{array}$} & \multirow{2}{*}{7} & 16 & Din eğitimine verilen önemin giderek artması & 4 & 57.15 \\
\hline & & 4.0 & Kılık kıyafete karışılması & 3 & 42.85 \\
\hline & & & Ailelerin üzerlerine düşeni yapmamaları & 2 & 33.35 \\
\hline & & & Sosyal medya ve olumsuz rol modeller & 1 & 16.66 \\
\hline Diğer sorunlar & 6 & 3.9 & Öğrenciler arası rekabet & 1 & 16.66 \\
\hline & & & Ödevlerin fazla ve niteliksiz olması & 1 & 16.66 \\
\hline & & & Türkçe'nin yanlış kullanımı & 1 & 16.66 \\
\hline
\end{tabular}

Tablo 2 incelendiğinde öğretmen adaylarının medyaya yansıyan haberler üzerinden Türk eğitim sisteminin sorunları ile ilgili toplam 152 farklı görüşe vurgu yaptıkları görülmektedir. Öğretmen adayları tarafından en sık ifade edilen sorunların şiddet, eğitim politikaları ile ilgili sorunlar, öğretmenlik mesleği ile ilgili sorunlar ve eğitimde fırsat eşitsizliği ile ilgili sorunlar temaları altında toplandıkları görülmektedir. Bu temaları yükseköğretimle ilgili sorunlar, öğretim programları ile ilgili sorunlar, kişisel tercihlere saygı göstermede yaşanan sorunlar, diğer sorunlar takip etmektedir. 
Şiddet teması altında yer alan toplam 54 ifadenin 4 alt tema altında toplandığı belirlenmiştir. Bu alt temalar şu şekilde ifade edilmiştir:

Öğretmene şiddet ( $f=34)$, eğitim paydaşları arasındaki şiddet $(f=11)$, öğrenciye şiddet $(f=7)$, öğrenciler arasındaki şiddet $(f=2)$. Buna göre aday öğretmenler tarafından "şiddet" temasında en sık ifade edilen sorun "öğretmene şiddet" alt temasında olmuştur. Aday öğretmenler tarafından öğretmene şiddet alt teması kapsamında ifade edilen yorumlara bir örnek aşağıdaki gibidir.

“Öğrencisi tarafından öldürülen bir öğretmen... Henüz yeni akademisyen olmuş, yeni evlenmiş, tam olarak 27 yaşında hayatı bir öğrencisi tarafından sonlandırılan Ceren Damar Şenel... (Ingilizce Öğretmenliği, Kadın)"

Eğitim politikaları ile ilgili sorunlar teması altında yer alan toplam 29 ifadenin 11 alt tema altında toplandığı belirlenmiştir. Bu alt temalar şu şekilde ifade edilmiştir: Üst kademeye geçiş sınavları ile ilgili sorunlar $(f=7)$, yanlış eğitim politikaları ( $f=4)$, mesleki ve teknik eğitimdeki sorunlar $(f=3)$, okul öncesi eğitimin zorunlu olmaması $(f=2)$, Türk eğitim sisteminin gelişimindeki eksiklik $(f=2)$, eğitim finansmanındaki sorunlar $(f=2)$, liselere sınavsız geçiş $(f=2)$, ortaöğretim sisteminin yenilenmesi $(f=2)$, özel okul sayısındaki $\operatorname{artış~(~} f=2)$, ikili öğretimin sona ermesi $(f=2)$, okullarda rehberlik hizmetlerine önem verilmemesi ( $f=1)$. Buna göre aday öğretmenler tarafından "eğitim politikaları ile ilgili sorunlar" temasında en sık ifade edilen sorun "üst kademeye geçiş sınavları ile ilgili sorunlar" alt temasında olmuştur. Aday öğretmenler tarafından eğitim politikaları ile ilgili sorunlar teması kapsamında ifade edilen yorumlara bir örnek aşağıdaki gibidir.

...Eğitim sisteminin mümkün olduğunca yetenek ve becerilere dayalı olması taraftarıyım. Genç nüfus fazlalığı dolayısıyla insanları seçmenin başka bir yolu yok gibi gözüküyor. Mesela sınavların birkaç şıklı sorulara bırakılmaması lazım. Bu durum derslerin -her ne kadar öğretmenler bunu tercih etmese de - ezbere dayalı olmasına sebep oluyor (illköğretim Matematik Öğretmenliği, Kadın).

Öğretmenlik mesleği ile ilgili sorunlar teması altında yer alan toplam 15 ifadenin 3 alt tema altında toplandı̆̆ı belirlenmiştir. Bu alt temalar şu şekilde ifade edilmiştir: Öğretmen yetiştirme ve atama sürecindeki sorunlar ( $f=8$ ), öğretmenlik mesleğinin itibarının azalması $(f=5)$, öğretmenlerin doğuda görev yapmaktan kaçınması ( $f=2$ ). Buna göre aday öğretmenler tarafından "öğretmenlik mesleği ile ilgili sorunlar" temasında en sık ifade edilen sorun "öğretmen yetiştirme ve atama sürecindeki sorunlar" alt temasında olmuştur. Aday öğretmenler tarafından öğretmenlik mesleği ile ilgili sorunlar teması kapsamında ifade edilenlerden bir örnek aşağıdaki gibidir.

"Ülkemizde öğretmen olmak çok kolay ya üniversitelerde eğitim fakültelerinden ders alıp öğretmen oluyorsun ya da fen fakültesini bitirip 1 yıl da formasyon eğitimi alıyorsun sonuçöğretmen. Aslında bu durum bu kadar kolay olmamalı. (Kimya Öğretmenliği, Kadın)"

2023 Eğitim Vizyonu ile yapılacak değişikliklere yönelik sorunlar teması altında yer alan toplam 12 ifadenin 4 alt tema altın da toplandığı belirlenmiştir. Bu alt temalar şu şekilde ifade edilmiştir: 40 dakika ders, 40 dakika teneffüs uygulaması ( $f=6)$, Gözetimsiz sınav önerisi ( $f=3)$, Okul öncesi döneme yönelik yaz okulu eğitimleri ( $f=2$ ), Özel öğretime teşviklerin kademeli olarak kaldırılması $(f=1)$. Buna göre aday öğretmenler tarafından "2023 Eğitim Vizyonu ile yapılacak değişikliklere yönelik sorunlar" temasında en sık ifade edilen sorun " 40 dakika ders, 40 dakika teneffüs uygulaması" alt temasında olmuştur. Aday öğretmenler tarafından bu kapsamda ifade edilenlerden bir örnek aşağıdaki gibidir:

"OKUL 2023 projesinde ortaya çıkabilecek uygulama sorunları -40 dk ders 40 dakika teneffüs uygulaması - teneffüs zamanları 40 dakika olacak, öğrenci ve veliler tarafından belirlenen etkinlikler teneffüs zamanlarında yapılacak, bu etkinlikler, ek ders ücreti karşılığında talep eden öğretmenler tarafından gözetim altından tutulacak. (Fransız Dili Eğitimi, Kadın)”

Eğitimde fırsat eşitsizliği ile ilgili sorunlar teması altında yer alan toplam 10 ifadenin 4 alt tema altında toplandı̆̆ı belirlenmiştir. $\mathrm{Bu}$ alt temalar şu şekilde ifade edilmiştir: Eğitimde cinsiyetçi yaklaşımlar $(f=4)$, göçmenlerin eğitimi $(f=3)$, engelli öğrencilerin eğitiminde yaşanan sorunlar ( $f=2$ ), okullar arası başarı farkları $(f=1)$. Buna göre aday öğretmenler tarafından "eğitimde fırsat eşitsizliği ile ilgili sorunlar" temasında en sık ifade edilen sorun "eğitimde cinsiyetçi yaklaşımlar" alt temasında olmuştur. Aday öğretmenler tarafından bu kapsamda ifade edilenlerden bir örnek aşağıdaki gibidir:

"Türkiye'de köklerini geçmişten bugüne dayandıran töre, değiştirilemez bakış açıları, kültürel kalıntılar, örf, adetler, eğitimde fırsat eşitliğini engelleyici unsurlar olarak karşımıza çıkmaktadır. Kadın ve erkeğin eşit olması ve birlikte eğitime katılmaları gerçeği karşııında gelenekçi tutumlar, kız çocuklarının okutulmasına karşı çıkmakta ya da buna gerek görmemektedir. Türkiye'de kız çocuklarının okutulmamasının önemli nedenleri tutuculuk ve dinsel bağnazlıktır. Bu gibi tutumlar modern anlayışla çatışmasına rağmen günümüzde ülkemizde halen rastladığımız tutumlardır (Okul Öncesi Öğretmenliği, Kadın)."

Öğretim programları ile ilgili sorunlar teması altında yer alan toplam 10 ifadenin 7 alt tema altında toplandığı belirlenmiştir. Bu alt temalar şu şekilde ifade edilmiştir: müfredattaki eksikler $(f=2)$, yabancı dil eğitiminde yaşanan sorunlar $(f=2)$, uzaktan eğitim programlarındaki sorunlar ( $f=2)$, kodlama eğitimine önem verilmemesi $(f=1)$, girişimcilik programlarındaki eksiklikler ( $f=1)$, iş sağlı̆̆ı güvenliğinin programda olmaması $(f=1)$ öğretim programlarının öğrencilerin ilgi ve yeteneklerine yönelik olmaması ( $f=1)$. Buna göre aday öğretmenler tarafından "Öğretim programları ile ilgili sorunlar" temasında en sık ifade edilen sorunlar "müfredattaki eksikler", "yabancı dil eğitiminde yaşanan sorunlar" ve "uzaktan eğitim programlarındaki sorunlar" alt temalarında olmuştur. Aday öğretmenler tarafından öğretim programları ile ilgili sorunlar teması kapsamında ifade edilen yorumlara aşağıdakiler örnek verilebilir. 
"Bu haberi eğitimsel bir sorun ya da bir olgu olarak değerlendirmek istersek kesinlikle çıkaracağımız sonuç eğitim ve sınav sistemimizin ezbere dayalı direttiği yol sebebiyle öğrencilerimizin mantıksal ve çözüm odaklı yorum yapabilme konusunda genel açıdan başarısız olduğu gerçeğidir. (İngiliz Dili Eğitimi, Erkek)"

"Haberde de yazıldığı gibi bireyler ingilizce eğitimine büyük bütçe ayırmakta, ancak ayrılan bu bütçe ve zamanla ingilizce başarısının orantısız olduğu yapılan sınavlarla ortaya çıkmaktadır." (Ingiliz Dili Eğitimi, Kadın)

"Buraya kadar genelde hep uzaktan eğitim aşağıda bahsedilen olumsuz etkileri yaratabilir;

- Öğrencilerin öğretmenin jest ve mimik hareketleri, ses tonu gibi anlatımı etkili kılacak unsurlardan yararlanamaması.

- Uzun süreli bilgisayar kullanımı sonucunda oluşan sağlık sorunları.

- $\quad$ Öğretmen ve öğrencilerin teknoloji konusundaki eksik eğitimi ve internet üzerinden eğitimin getireceği faydalardan yararlanamamaları.

- Kırsal bölgelerde internete girebilmenin sorun olması

- Televizyonda olduğu gibi pasif olarak izlemeye neden olabilmesi.

- Ö̈rrenciler arasında kültürel etkileşim, birliktelik gibi sosyolojik ve psikolojik unsurların sağlanamaması." (Psikolojik Danışmanlık ve Rehberlik, Kadın)

Yükseköğretimle ilgili sorunlar teması altında yer alan toplam 9 ifadenin 5 alt tema altında toplandığı belirlenmiştir. Bu alt temalar şu şekilde ifade edilmiştir: Okul terki $(f=3)$, üniversite öğrencilerinin kariyer sorunu ( $f=3)$, niteliksiz eğitim ( $f=1)$, lisansüstü eğitimde yaşanan sorunlar $(f=1)$, işsizlik korkusu $(f=1)$. Buna göre aday öğretmenler tarafından "yükseköğretimle ilgili sorunlar" temasında en sık ifade edilen sorun "okul terki" alt temasında olmuştur. Aday öğretmenlerin bu kapsamdaki ifadelerinden bazıları aşağıdaki gibidir:

"Günümüzde üniversitelerde eğitimini kendi isteği ile sonlandıran öğrencilerin sayısının artması önemli bir sorundur. Gençlerin öğretim hayatları boyunca kendilerine tek amaç olarak gördükleri üniversitede okuma hayalleri için on iki yıl boyunca çabaladıkları ve bu süreç nihayetinde kazandıkları üniversitelerden toplumun ve dönemin olumsuz etkileri karşısında ayrılmak zorunda bırakıldıkları bir sorunun içindeyiz. (Fransız Dili Eğitimi, Kadın)"

"Eğitimcilerin öğrencilerle yeterince ilgilenmemesi ve kariyer planlamasında yardıma olmaması bir sorundur. Yapılan bir araştırmada, öğrencilerin yüzde 65'i üniversitelerinin kariyerlerini geliştirme konusundaki faaliyetlerini yetersiz bulduğu kanıtlanmış. Eğer yeterli etkinlik yapılmaz ve nasıl bir yol çizecekleri hakkında bilgilendirilmezlerse kariyer sorunu oluşacaktır. (İngiliz Dili Öğretmenliği, Erkek)"

Kişisel tercihlere saygı göstermede yaşanan sorunlar teması altında yer alan toplam 7 ifadenin 2 alt tema altında toplandığı belirlenmiştir. Bu alt temalar şu şekilde ifade edilmiştir: Din eğitimine verilen önemin giderek artması ( $f=4)$, Kılık kıyafete karışılması $(f=3)$. Buna göre aday öğretmenler tarafından "kişisel tercihlere saygı göstermede yaşanan sorunlar" temasında en sık ifade edilen sorun "Din eğitimine verilen önemin giderek artması" alt temasında olmuştur. Aday öğretmenler tarafından bu kapsamda ifade edilenlerden bir örnek aşağıdaki gibidir:

"Avrupa insan Hakları Mahkemesi'nin mahkûmiyet kararlarına rağmen zorunlu din dersinin kaldırılmaması; temel kavramları çatışma, değişme, zorlama olan ve temeli sosyo-politik kontrolün sağlanması olan çatışmacı kuramlar ile bağdaştırılabilir. Milli eğitimin, ailenin velisi oldukları öğrencinin din dersinden muaf tutulma talebini reddetmesi ve dini görüşünü belgelendirmesini talep etmesi eğitimin bir diğer temel ilkesi olan ve "Milli eğitimde laiklik esas alınır. Din kültürü ve ahlak bilgisi gibi dersler devlet kontrolünde öğretilir." şeklinde belirtilen laiklik ilkesine doğrudan ters düşmektedir (İngiliz Dili Eğitimi, Kadın)."

Diğer sorunlar teması altında yer alan toplam 6 ifadenin 5 alt tema altında toplandığı belirlenmiştir. Bu alt temalar şu şekilde ifade edilmiştir: Ailelerin üzerlerine düşeni yapmamaları $(f=2)$, sosyal medya ve olumsuz rol modeller $(f=1)$, öğrenciler arası rekabet $(f=1)$, ödevlerin fazla ve niteliksiz olması $(f=1)$, Türkçenin yanlış kullanımı $(f=1)$. Buna göre aday öğretmenler tarafından "diğer sorunlar" temasında en sık ifade edilen sorun "Ailelerin üzerlerine düşeni yapmamaları" alt temasında olmuştur. Aday öğretmenler tarafından bu kapsamda ifade edilenlerden bir örnek aşağıdaki gibidir:

"Aile ve eğitim arasındaki ilişki, çok sayıda faktör ile açıklanabilir. Bunlardan biri, kurumsallaşmadan önce eğitimin yalnızca aile içinde olması, günümüzde ise aileden devralınan bu rolün eğitim kurumlarınca yürütülmesi olabilir. Çünkü ailenin kazandırdığı değer yargıları yalnız çocuğun okul başarısını etkilemekle kalmaz, kişisel başarısını da etkiler ve çocuk genellikle ailede kazandığı bu değer yargıları ile yaşamını sürdürür ve şekillendirir. Dolayısıyla aileye önemli bir rol düşer (Fransız Dili Eğitimi, Erkek)."

\section{Türk Eğitim Sisteminin Sorunlarının Çözümüne ilişkin Bulgular}

Çalışmadan elde edilen bulgulardan bir diğeri ise öğretmen adaylarının eğitim sisteminde sorun olarak gördükleri durumların nasıl çözümlenebileceğine ilişkin önerileridir. Söz konusu öneriler içerik analizi ile değerlendirilmiş; analiz sonucunda temalar ve alt temalar halinde bu bölümde sunulmuştur. İçerik analizi sonucunda eğitim politikalarının geliştirilmesi, toplumsal bilinç kazandırıması, istihdam politikalarının geliştirilmesi, eğitim programlarının güncellenmesi, güvenlik, etkili eğitim yönetimi, öğretmen faktörü, aile faktörü ve demokratik eğitim olmak üzere dokuz ana tema ortaya çıkarılmıştır. Bu dokuz ana temaya ait frekans ve yüzde değerleri Tablo 3'te yer almaktadır. 
Tablo 3. Öğretmen adaylarının görüşlerine göre Türk eğitim sisteminin sorunlarına yönelik çözüm önerileri

\begin{tabular}{|c|c|c|c|c|c|}
\hline Tema & $f$ & $\%$ & Alt Temalar & $f$ & $\%$ \\
\hline \multirow{20}{*}{$\begin{array}{l}\text { Eğitim politikalarının } \\
\text { geliştirilmesi }\end{array}$} & \multirow{20}{*}{81} & \multirow{20}{*}{31.5} & Rehberlik hizmetlerinin geliştirilerek etkili bir şekilde uygulanması & 18 & 22.2 \\
\hline & & & İnsanların bir bütün olarak eğitilmesi & 13 & 16.0 \\
\hline & & & Devletin madde ve insan kaynağını arttırması & 11 & 13.6 \\
\hline & & & Dezavantajlı bölge, okul ve öğrencilere destek & 10 & 12.3 \\
\hline & & & Eğitim sisteminin değiştirilmesi & 5 & 6.2 \\
\hline & & & Yabancıların eğitimi için etkin politikalar benimseme & 4 & 4.9 \\
\hline & & & Ortaöğretimde yeni politikaların uygulanması & 3 & 3.7 \\
\hline & & & Eğitime katılımın arttırılması & 3 & 3.7 \\
\hline & & & $\begin{array}{c}2023 \text { vizyonundaki } 40 \text { dakika ders } 40 \text { dakika teneffüs uygulaması yerine daha } \\
\text { verimli olabilecek uygulamaların planlanması }\end{array}$ & 2 & 2.5 \\
\hline & & & Okul öncesi eğitimin zorunlu ve parasız olması & 2 & 2.5 \\
\hline & & & Liselere sınavla girebilecek öğrenci sayısının artırııması & 1 & 1.2 \\
\hline & & & Öğrencilerin donanımlı bireyler olarak yetiştirilmesi & 1 & 1.2 \\
\hline & & & $4+4+4$ sisteminin kaldırılması & 1 & 1.2 \\
\hline & & & Özel okullara teşvikin kaldırılması & 1 & 1.2 \\
\hline & & & Meslek liselerinin kalitesinin artırılması ve tanıtımlarının yapılması & 1 & 1.2 \\
\hline & & & Sınav sorularının en azından kavrama basamağında olması & 1 & 1.2 \\
\hline & & & Sık değişmeyen sağlam temelli bir sistem & 1 & 1.2 \\
\hline & & & Üniversite öğrencilerine sağlanan imkânların artırılması & 1 & 1.2 \\
\hline & & & $\begin{array}{l}\text { Üniversiteye giriş sınavının birinci ve ikinci dönemde olmak üzere iki aşamada } \\
\text { yapılması }\end{array}$ & 1 & 1.2 \\
\hline & & & Kadınların eğitimi & 1 & 1.2 \\
\hline \multirow{2}{*}{$\begin{array}{l}\text { Toplumsal bilinç } \\
\text { kazandırılması }\end{array}$} & \multirow{2}{*}{36} & \multirow{2}{*}{14} & Eğitimle bütün toplumun bilinçlendirilmesi & 28 & 77.8 \\
\hline & & & Medyanın bilinçlendirici işlevini kullanması & 8 & 22.2 \\
\hline \multirow{2}{*}{$\begin{array}{l}\text { İstihdam politikalarının } \\
\text { geliştirilmesi }\end{array}$} & \multirow[t]{2}{*}{35} & \multirow[t]{2}{*}{13.6} & $\begin{array}{c}\text { Öğretmen yetiştirme, istihdam ve performans değerlendirme politikalarının } \\
\text { düzenlenmesi }\end{array}$ & 33 & 94.3 \\
\hline & & & İstihdam politikalarının değiştirilmesi & 2 & 5.7 \\
\hline \multirow{8}{*}{$\begin{array}{l}\text { Eğitim programlarının } \\
\text { güncellenmesi }\end{array}$} & \multirow{8}{*}{31} & \multirow{8}{*}{12.1} & Öğretim programlarının etkin biçimde düzenlenmesi & 21 & 67.7 \\
\hline & & & Öğrencilere kişisel gelişim fırsatları sunulması & 3 & 9.7 \\
\hline & & & İletişim becerilerinin geliştirilmesi & 2 & 6.5 \\
\hline & & & İnsanların bütünleştirilmesi & 1 & 3.2 \\
\hline & & & Eğitimin bilimsel olması & 1 & 3.2 \\
\hline & & & Çeşitli kulüpler ve eğitsel kollar & 1 & 3.2 \\
\hline & & & Öğretmenlerin farklı öğrenme etkinlikleri düzenlemesi & 1 & 3.2 \\
\hline & & & Bireysel değerlerin yanında toplumsal değerlerin de göz önünde bulundurulması & 1 & 3.2 \\
\hline \multirow{6}{*}{ Güvenlik } & \multirow{6}{*}{29} & \multirow{6}{*}{11.3} & Güvenlik önlemlerinin artırılması & 16 & 55.2 \\
\hline & & & Hukuki ve toplumsal yaptırımların ağırlaştırılması & 9 & 31 \\
\hline & & & Şiddeti önleyici eylem planları oluşturulması & 1 & 3.4 \\
\hline & & & Şiddet olaylarının sıradanlaştırılmaması & 1 & 3.4 \\
\hline & & & Eğitim kurumlarında, şiddet ile ilgili farkındalık yaratacak etkinlikler düzenleme & 1 & 3.4 \\
\hline & & & Şiddetle sistematik mücadele & 1 & 3.4 \\
\hline \multirow{10}{*}{ Etkili eğitim yönetimi } & \multirow{10}{*}{26} & \multirow{10}{*}{10.1} & Paydaşlarla işbirliği ve katılımlı karar alma & 6 & 23.1 \\
\hline & & & MEB'in diğer kuruluşlar ile etkin işbirliği yapması & 3 & 11.5 \\
\hline & & & Okul yönetiminin etkin çalışması & 3 & 7.7 \\
\hline & & & Sınıftaki öğrenci sayısının azaltılması & 2 & 7.7 \\
\hline & & & Gözetimsiz sınava doğrudan geçilmemesi & 2 & 7.7 \\
\hline & & & Kişiler ve kurumlar arası işbirliği & 2 & 7.7 \\
\hline & & & Yeni kararlar uygulanırken önce alt yapısını oluşturmak & 2 & 7.7 \\
\hline & & & Adrese dayalı okul sisteminden vazgeçilmesi & 2 & 7.7 \\
\hline & & & Yapılacak değişikliklerin zamanında duyurulması & 1 & 3.8 \\
\hline & & & Okul bitiş saatinin geç olmaması & 1 & 3.8 \\
\hline
\end{tabular}




\begin{tabular}{|c|c|c|c|c|c|}
\hline Tema & $\mathrm{f}$ & $\%$ & Alt Temalar & $\mathrm{f}$ & $\%$ \\
\hline & & & Denetimlerin sıklaştırılması & 1 & 3.8 \\
\hline & & & Öğleden önce ders öğleden sonra etkinlik olması & 1 & 3.8 \\
\hline \multirow[t]{2}{*}{ Öğretmen faktörü } & \multirow[t]{2}{*}{8} & \multirow[t]{2}{*}{3.1} & $\begin{array}{c}\text { Öğretmenlerin öğrencilere karşı olumlu ve destek sağlayıcı tutum ve davranışlarda } \\
\text { bulunarak onlara iyi birer rol model olması }\end{array}$ & 7 & 87.5 \\
\hline & & & Eğitimcilerin öğrencilere daha anlayışlı yaklaşması & 1 & 12.5 \\
\hline \multirow{3}{*}{ Aile faktörü } & \multirow{3}{*}{7} & \multirow{3}{*}{2.7} & Küçüklükten başlayan eğitim & 5 & 71.4 \\
\hline & & & Ailelerin çocuklarının tercihine saygı duyarak onları koşulsuz sevmesi & 1 & 14.3 \\
\hline & & & Ailelerin çocukları baskı altına almadan yetiştirmesi & 1 & 14.3 \\
\hline \multirow{4}{*}{ Demokratik eğitim } & \multirow{4}{*}{4} & \multirow{4}{*}{1.6} & Eğitim kurumlarında demokratikleşme & 1 & 25 \\
\hline & & & İsteyen her öğrencinin din derslerinden muaf tutulması & 1 & 25 \\
\hline & & & Devletin yalnızca bir dine değil tüm dinlere hoşgörülü olması & 1 & 25 \\
\hline & & & Zorla dini öğretilerde bulunulmaması & 1 & 25 \\
\hline Toplam & 25 & 100 & & 257 & 100 \\
\hline
\end{tabular}

Tablo 3'ten de görülebileceği gibi öğretmen adayları en çok eğitim politikalarının geliştirilmesi ile ilgili çözüm önerileri sunmuştur.

Eğitim politikalarının geliştirilmesi teması altında yer alan toplam 81 ifadenin 20 alt tema altında toplandığı görülmüştür. Bu alt temalara ait frekans değerleri şu şekildedir: Rehberlik hizmetlerinin geliştirilerek etkili bir şekilde uygulanması ( $\mathrm{f}=18$ ), İnsanların bir bütün olarak eğitilmesi $(f=13)$, devletin madde ve insan kaynağını arttırması $(f=11)$, dezavantajı bölge, okul ve öğrencilere destek $(f=10)$ eğitim sisteminin değiştirilmesi $(f=5)$, yabancıların eğitimi için etkin politikalar benimseme $(f=4)$, ortaöğretimde yeni politikaların uygulanması ( $f=3)$, eğitime katılımın arttırılması $(f=3), 2023$ vizyonundaki 40 dakika ders 40 dakika teneffüs uygulaması yerine daha verimli olabilecek uygulamaların planlanması $(f=2)$, okul öncesi eğitimin zorunlu ve parasız olması $(f=2)$, liselere sınavla girebilecek öğrenci sayısının artırılması, öğrencilerin donanımlı bireyler olarak yetiştirilmesi, 4+4+4 sisteminin kaldırılması ( $f=1$ ), özel okullara teşvikin kaldırıması $(f=1)$, meslek liselerinin kalitesinin artırılması ve tanıtımlarının yapılması $(f=1)$, sınav sorularının en azından kavrama basamağında olması $(f=1)$, sık değişmeyen sağlam temelli bir sistem $(f=1)$, üniversite öğrencilerine sağlanan imkânların artırılması ( $f=1)$, üniversiteye giriş sınavının birinci ve ikinci dönemde olmak üzere iki aşamada yapılması ( $f=1)$, kadınların eğitimi ( $f=1)$. Buna göre aday öğretmenler tarafından "eğitim politikalarının geliştirilmesi" temasında en sık ifade edilen çözüm önerisi "rehberlik hizmetlerinin geliştirilerek etkili bir şekilde uygulanması" alt temasında olmuştur. Aday öğretmenlerin bu tema altında yer alan ifadelerine şu şekilde bir örnek verilebilir:

"Okullarda öğrencilere yönelik rehberlik çalışmaları artırılmalı, her öğrencinin rahatıkla rehberlik servislerine erişip erişemediği denetlenmelidir (İngiliz Dili Eğitimi, Kadın)."

Toplumsal bilinç kazandırılması teması altında yer alan toplam 36 ifadenin 2 alt tema altında toplandığı görülmüştür. Bu alt temalara ait frekans değerleri şu şekildedir: Eğitimle bütün toplumun bilinçlendirilmesi $(f=28)$ ve medyanın bilinçlendirici işlevini kullanması $(\mathrm{f}=8)$. Buna göre aday öğretmenler tarafından "toplumsal bilinç kazandırılması" temasında en sık ifade edilen çözüm önerisi "Eğitimle bütün toplumun bilinçlendirilmesi" alt temasında olmuştur. Aday öğretmenlerin bu tema altında yer alan ifadelerine şu şekilde bir örnek verilebilir:

"insanlar, birbirlerinin fikirlerine saygılı olma, değişime açık olma ve dogmatik yüksekliklere yerleştirilmiş toplumsal normlardan kurtulma konusunda eğitilmelidir (Ingiliz Dili Eğitimi, Erkek)."

İstihdam politikalarının geliştirilmesi teması altında yer alan toplam 35 ifadenin 2 alt tema altında toplandığı görülmüştür. Bu alt temalara ait frekans değerleri şu şekildedir: Öğretmen yetiştirme ve istihdam ve performans değerlendirme politikalarının düzenlenmesi ( $f=33)$, istihdam politikalarının değiştirilmesi (tüm meslekler için) $(f=2)$. Buna göre aday öğretmenler tarafından "İstihdam politikalarının geliştirilmesi” temasında en sık ifade edilen çözüm önerisi “öğretmen yetiştirme, istihdam ve performans değerlendirme politikalarının düzenlenmesi” alt temasında olmuştur. Aday öğretmenlerin bu tema altında yer alan ifadelerine şu şekilde bir örnek verilebilir:

“Öğretmenlik belli bir yaşa kadar yapılmalı çünkü öğretmenler bir süre sonra yaptıkları işlerden sıkılmaya başlıyor, sabırlarını yitiriyorlar ve kendilerini geliştirmeyi bırakıp verimsizleşiyorlar. Bu yaşın öğretmenler üzerinde araştırma yapılıp belirlenmesi daha doğru olacaktır. Bazı ülkelerde öğretmenlik bölümünü kazanmak daha yüksek bir başarı gerektiriyor hatta tıp ile aynı puan değerine sahip oluyor. Bu durum daha çalışkan ve zeki öğretmenlerin olmasına olanak sağlamaktadır.(Ingiliz Dili Eğitimi, Kadın)”

Eğitim programlarının güncellenmesi teması altında yer alan toplam 31 ifadenin 8 alt tema altında toplandığı görülmüştür. Bu alt temalara ait frekans değerleri şu şekildedir: Öğretim programlarının etkin biçimde düzenlenmesi ( $f=21)$, öğrencilere kişisel gelişim fırsatları sunulması $(f=3)$, iletişim becerilerinin geliştirilmesi $(f=2)$, insanların bütünleştirilmesi $(f=1)$, eğitimin bilimsel olması $(f=1)$, çeşitli kulüpler ve eğitsel kollar $(f=1)$, öğretmenlerin farklı öğrenme etkinlikleri düzenlemesi $(f=1)$, bireysel değerlerin yanında toplumsal değerlerin de göz önünde bulundurulması $(f=1)$. Buna göre aday öğretmenler tarafından "eğitim programlarının güncellenmesi” temasında en sık ifade edilen çözüm önerisi “öğretim programlarının etkin biçimde düzenlenmesi” alt temasında olmuştur. Aday öğretmenlerin bu tema altında yer alan ifadelerine şu şekilde bir örnek verilebilir: 
"Avrupa ile bilimde, teknolojide, tarımda rekabet etmek istiyorsak, ezberci eğitim sistemden vazgeçip, eleştirel düşünceyi ön plana çıkarabilecek eğitim sistemine yönelmeli ve biran evvel eğitimin niteliği ve içeriğini değiştirmeliyiz (İngiliz Dili Eğitimi, Erkek)"

Güvenlik teması altında yer alan toplam 29 ifadenin 6 alt tema altında toplandığı görülmüştür. Bu alt temalara ait frekans değerleri şu şekildedir: Güvenlik önlemlerinin artırılması $(f=16)$, hukuki ve toplumsal yaptırımların ağırlaştırılması ( $f=9$ ), şiddeti önleyici eylem planları oluşturulması $(f=1)$, şiddet olaylarının sıradanlaştırılmaması $(f=1)$, eğitim kurumlarında, şiddet ile ilgili farkındalık yaratacak etkinlikler düzenleme $(f=1)$, şiddetle sistematik mücadele $(f=1)$. Buna göre aday öğretmenler tarafından "güvenlik" temasında en sık ifade edilen çözüm önerisi "güvenlik önlemlerinin artırılması" alt temasında olmuştur. Aday öğretmenlerin bu tema altında yer alan ifadelerine şu şekilde bir örnek verilebilir:

"EGM okul, hastane gibi kurumlarda ya da diğer özel kurumlarda, üniversite nizamiyelerinde özel güvenlikler haricinde çalışmak üzere polis memurları görevlendirilebilir. Okul girişlerinde yalnızca öğrenci kimliği kontrolü değil gerektiğinde x-ray yardımıyla aramalar; eğer okul mevcudu çok ise okul içerisinde kantin, restoran, kütüphane gibi yerlerin giriş kapılarında silah, bıçak vb. zarar verici aletlerin kullanımını önlemek ve fiziksel şiddeti durdurmak amacı ile x-ray kullanılarak aramalar yapılabilir (Ingiliz Dili Eğitimi, Kadın)."

Etkili eğitim yönetimi teması altında yer alan toplam 26 ifadenin 12 alt tema altında toplandığı görülmüştür. Bu alt temalara ait frekans değerleri şu şekildedir: Paydaşlarla işbirliği ve katılımlı karar alma ( $f=6)$, MEB'in diğer kuruluşlar ile etkin işbirliği yapması $(f=3)$, okul yönetiminin etkin çalışması $(f=3)$, sınıftaki öğrenci sayısının azaltılması $(f=2)$, gözetimsiz sınava doğrudan geçilmemesi $(f=2)$, kişiler ve kurumlar arası işbirliği $(f=2)$, yeni kararlar uygulanırken önce alt yapısını oluşturmak $(f=2)$, adrese dayalı okul sisteminden vazgeçilmesi $(f=2)$, yapılacak değişikliklerin zamanında duyurulması $(f=1)$, okul bitiş saatinin geç olmaması $(f=1)$, denetimlerin sıklaştırılması ( $f=1)$, öğleden önce ders öğleden sonra etkinlik olması $(f=1)$. Buna göre aday öğretmenler tarafından "etkili eğitim yönetimi" temasında en sık ifade edilen çözüm önerisi "paydaşlarla işbirliği ve katılımlı karar alma" alt temasında olmuştur. Aday öğretmenlerin bu tema altında yer alan ifadelerine şu şekilde bir örnek verilebilir:

“Lise öğrencilerinden, öğrenci adaylarından, velilerden, öğretmenlerden çıkan ortak bir demokratik düşünceyle, sistemin ne şekilde işlemesi gerektiğine karar vermek bu durumda en mantıklı çözüm olacaktır (İngiliz Dili Eğitimi, Kadın)."

Öğretmen faktörü teması altında yer alan toplam sekiz ifadenin iki alt tema altında toplandığı görülmüştür. Bu alt temalara ait frekans değerleri şu şekildedir: Öğretmenlerin öğrencilere karşı olumlu ve destek sağlayıcı tutum ve davranışlarda bulunarak onlara iyi birer rol model olması $(f=7)$ ve eğitimcilerin öğrencilere daha anlayışlı yaklaşması $(f=1)$. Buna göre aday öğretmenler tarafından “öğretmen faktörü” temasında en sık ifade edilen çözüm önerisi “öğretmenlerin öğrencilere karşı olumlu ve destek sağlayıcı tutum ve davranışlarda bulunarak onlara iyi birer rol model olması" alt temasında olmuştur. Aday öğretmenlerin bu tema altında yer alan ifadelerine şu şekilde bir örnek verilebilir:

"Donanımlı öğretmenler olmalıyız ki gelecek nesil öğretmenlerini örnek alsın ve öğretmen olmayı küçük bir şey olarak görmesin. Onların gönüllerine dokunup gönül bağı kurabilelim (PDR, Kadın)."

Aile faktörü teması altında yer alan toplam 7 ifadenin 3 alt tema altında toplandığı görülmüştür. Bu alt temalara ait frekans değerleri şu şekildedir: Küçüklükten başlayan eğitim ( $f=5)$, ailelerin çocuklarının tercihine saygı duyarak onları koşulsuz sevmesi $(f=1)$, ailelerin çocukları baskı altına almadan yetiştirmesi $(f=1)$. Buna göre aday öğretmenler tarafından "aile faktörü" temasında en sık ifade edilen çözüm önerisi "küçüklükten başlayan eğitim" alt temasında olmuştur. Aday öğretmenlerin bu tema altında yer alan ifadelerine şu şekilde bir örnek verilebilir:

"Bu gibi sorunlarla başa çıkmak için toplumumuzun en küçük yapı taşından, aileden başlayan bir bilinçlenme olmalıdır. Küçüklüğünde çocuklara verilen informal eğitim gelecekteki davranışlarına yön verdiğinden dolayı büyük bir öneme sahiptir (Ingiliz Dili Eğitimi, Erkek)."

Demokratik eğitim teması altında yer alan toplam dört ifadenin dört alt tema altında toplandığı görülmüştür. Bu alt temalar şu şekildedir: Ĕgitim kurumlarında demokratikleşme $(f=1)$, isteyen her öğrencinin din derslerinden muaf tutulması ( $f=1)$, devletin yalnızca bir dine değil tüm dinlere hoşgörülü olması $(f=1)$, zorla dini öğretilerde bulunulmaması ( $f=1)$. Bu alt temalardan biri olan eğitim kurumlarında demokratikleşme temasına ait ifade şu şekildedir:

"Aileden okula hatta devlete kadar demokratikleşme gerçekleştirilmelidir ki, bu tür problemler daha gün yüzüne çıkmadan çözüme varabilsin (İngiliz Dili Eğitimi, Kadın)."

\section{TARTIŞMA ve SONUÇ}

Bu çalışmada aday öğretmenler tarafından medya haberlerine dayalı olarak en sık ifade edilen sorunlar şiddet, eğitim politikaları ile ilgili sorunlar ve öğretmenlik mesleği ile ilgili sorunlar olmuştur. Bu sorunları sırasıyla 2023 Eğitim Vizyonu kapsamında yapılacak değişikliklere yönelik sorunlar, eğitimde fırsat eşitsizliği ile ilgili sorunlar, yükseköğretimle ilgili sorunlar, öğretim programları ile ilgili sorunlar, kişisel tercihlere saygı göstermede yaşanan sorunlar, öğrenci kaynaklı sorunlar takip etmiştir.

Şiddet temasının detayları incelendiğinde sırasıyla öğretmene şiddet, eğitim paydaşları arasında şiddet, öğrenciye şiddet konularına dikkat çekildiği görülmektedir. Erdemli (2018) ve Gündüz (2015) çalışmalarında eğitimde şiddet konusunu ele almışlardır. Erdemli (2018) yaptığı çalışmada Ocak 2010-Aralık 2015 tarihleri arasında üç gazeteden öğretmene şiddet konusunda 99 haber elde ederek üzerinde çalışmıştır. Çalışmada en dikkat çekici bulgulardan biri 2010 yılında \%2 olan öğretmene yönelik şiddetle ilgili haber oranının yıllar içinde artarak 2015 yılında \%32,3'e ulaşmasıdır. Medyada artan oranlarda bu haberlere yer 
verilmesi bu araştırmada en önemli sorunun şiddet olarak ortaya çıkmasını desteklemektedir. Gündüz (2015), son sınıfta okuyan 300 öğretmen adayı ile yaptığı çalışmada katılımcılardan bugüne kadar eğitim ortamlarında tecrübe ettikleri ya da şahit oldukları bir şiddet olayını yazmalarını istemiştir. Öğrencilerin \%98'i kendi başından geçen bir hadiseyi yazmıştır. Bu bulgu göstermektedir ki, Türk eğitim sisteminin son seviyesine gelip de şiddet görmeyen öğrenci yok gibidir. Gerçek hayatta sıkça deneyimlenen bu durumun medya haberlerinde de karşılaşılması şaşırtıcı değildir.

Medya haberlerine dayalı olarak belirtilen en önemli ikinci sorun, eğitim politikaları ile ilgilidir. Alan yazın incelendiğinde Özdemir ve Kaplan (2017) tarafından aday öğretmenlerle yapılan araştırmada katılımcıların \%19'u eğitim politikaları ile ilgili sorunlara değinmiştir. Gedikoğlu (2005) da Türk eğitim sisteminin önemli sorunları içinde eğitim politikalarında sürekliliğin sağlanamamasına vurgu yapmıştır. Eğitim politikaları ile ilgili sorunlar kapsamında en sık ifade edilen sorunlardan ikisi geniş ölçekli sınavlar ve yanlış eğitim politikaları olmuştur. Alan yazın incelendiğinde Kartal (2013) tarafından 2010-2011 yılları arasında aday öğretmenlerin Türk eğitim sisteminde değiştirilmesini istedikleri noktaları tespit etmek amacıyla yürütülen çalışmanın bulgularına göre aday öğretmenlerin \%76,3'ünün ölçme-değerlendirme ve yönlendirme alt boyutunda merkezi sınavların kaldırılması gerektiğine vurgu yaptıkları görülmüştür. Çetin, Yazar, Aydın ve Yazıcı (2018) tarafından 2017-2018 eğitim-öğretim yılında birinci sınıfta okumakta olan 49 ilköğretim matematik bölümünden aday öğretmen ile yürütülen araştırmada da öğrencilerin \%20,4'ü sınav sistemini sorun olarak belirlemişlerdir.

Medya haberlerine dayalı olarak belirtilen en önemli üçüncü sorun, öğretmenlik mesleği ile ilgili sorunlardır. Alanyazın incelendiğinde öğretmenlik mesleği ile ilgili sorunların farklı önceliklerde olacak şekilde pek çok çalışmada üzerinde durulan bir sorun olması dikkat çekicidir (Çetin vd., 2018; Gedikoğlu, 2005; Hareket, Erdoğan ve Dündar, 2016; Kartal, 2013; Özdemir ve Kaplan, 2017; Şener, 2018; Taşdemir, 2015). Örneğin Yılmaz ve Altınkurt (2011) öğretmen adaylarının öğretmenlik mesleği ile ilgili sorunlar kapsamında öğretmen atamaları ile ilgili sorunlara vurgu yaptıklarını belirtirken, Şener'in (2018) çalışmasında ise öğretmenler öğretmen atamalarını ve mesleki değerin azalmasını birer sorun olarak gördüklerini ifade etmişlerdir.

Eğitimde fırsat eşitsizliği kapsamında en sık ifade edilen sorunlar "eğitimde cinsiyetçi yaklaşımlar ve göçmenlerin eğitimi" olmuştur. Çetin ve arkadaşları (2018) tarafından 2017-2018 eğitim-öğretim yılında birinci sınıfta okumakta olan 49 aday ilköğretim matematik öğretmeni ile yapılan araştırmada öğrencilerin \%4,9'u eğitimde fırsat eşitsizliğine dikkat çekmiştir. Taşdemir (2015) tarafından aday öğretmenlerle yürütülen çalışmada ise eğitimle ilgili sorunlar içinde beşinci sırada bölgeler arası eğitim eşitsizliği yer almıştır. Gedikoğlu (2005) da eğitim sistemimizin sorunları kapsamında fırsat eşitsizliğine vurgu yapmıştır. Kutlu-Abu, Bacanak ve Gökdere'nin (2016) çalışmasında ise aday öğretmenler tarafından sorun olarak sözü edilen konulardan biri eğitime erişimde eşitsizlik olmuştur.

Aday öğretmenler tarafından öğretim programları ile ilgili sorunlar kapsamında "müfredattaki eksikler, yabancı dil eğitiminde yaşanan sorunlar, uzaktan eğitim programlarındaki sorunlar" konularına dikkat çekilmiştir. Alanyazın incelendiğinde aday öğretmenler ve öğretmenlerle yürütülen farklı araştırmalarda da programla ilgili sorunlara değinildiği görülmektedir (Çetin vd., 2018; Şener, 2018; Taşdemir, 2015).

Aday öğretmenler tarafından diğer sorunlar kapsamında en çok "ailelerin üzerlerine düşeni yapmamaları, sosyal medya ve olumsuz rol modeller" konularına vurgu yapılmıştır. Şener (2018) ve Kutlu-Abu, Bacanak ve Gökdere'nin (2016) çalışmalarında da öğrenci kaynaklı sorunlara vurgu yapılmıştır.

Bu çalışmada öğretmen adayları en çok eğitim politikalarının geliştirilmesine yönelik çözüm önerilerinden söz etmiştir. Bu önerileri sırasıyla kamu eğitimi, istihdam politikalarının geliştirilmesi, eğitim programlarının güncellenmesi, güvenlik, etkili eğitim yönetimi, öğretmen faktörü, aile faktörü ve demokratik eğitime yönelik öneriler takip etmiştir.

Alan yazında bu çalışma ile benzer şekilde öğretmen adaylarının eğitim sisteminin sorunlarına yönelik çözüm önerilerinin incelendiği araştırmalar yer almaktadır. Bu çalışmalarda elde edilen bulgularda da öğretmen adaylarının benzer çözüm önerilerini sundukları görülmektedir. Örneğin, Özdemir ve Kaplan'ın (2017) çalışmasında öğretmen adayların en çok öğretmen yetiştirmede düzenlemeler yapılması, uygulamaya yönelik eğitimlerin düzenlenmesi, ezberci eğitimden kaçınılması, eğitim sisteminin sürekli değiştirilmemesi ve liyakatin sağlanması şeklindeki çözüm önerilerini ifade etmiştir. Bir diğer çalışmada ise öğretmen adayları, fiziksel altyapı, eğitim programı, öğretmen, eğitim ekonomisi, eğitim planlaması, demokratik eğitim, fırsat eşitliği, yöneltme ve sınav sistemi, eğitim anlayışı, sorumluluk bilinci ve eğitim felsefesini kapsayan çözüm önerilerinden söz etmiştir (Yeşil ve Şahan, 2015).

Eğitim sistemimizin sorunlarının ve bu sorunlara yönelik çözüm önerilerinin araştırmacılar tarafından incelendiği diğer çalışmalarda ise benzer şekilde öğretmen eğitimi ve istihdamına gereken özenin gösterilmesi (Uluğ, 1998; Abazaoğlu, Yıldırım ve Yıldızhan, 2016), eğitim politikaları, felsefeleri ve programlarının gözden geçirilerek etkili bir şekilde düzenlenmesi, eğitimin demokratik, milli ve kültürel değerlere uygun olması, eğitim kurumlarının performansını kamusal değerlendirmeye açık olması, yabancı dil eğitimine önem verilmesi, öğrencileri yöneltme faaliyetlerinin geliştirilmesi, üniversiteye geçiş için yeni düzenlemeler yapılması, geleceğe yönelik insan kaynağı planlaması yapılması, eğitimin merkeziyetçi yönetiminden vazgeçilmesi, okul-aile ilişkilerine önem verilmesi, eğitim planlamasında piyasa ihtiyaçlarının dikkate alınması (Arslan, 2004; Gedikoğlu, 2005; Uluğ, 1998), anne-baba eğitimi (Özdemir, 2007; Özel ve Zelyurt, 2016), istihdam politikalarının geliştirilmesi (Erikli, 2016), yaşam boyu öğrenmeye önem verilmesi (Güllüpınar, 2017) ve eğitim kurumlarının güvenliğine önem verilmesi (Delice ve Arslan, 2018; Öğülmüş, 2006) gibi çözüm önerilerinin ön plana çıktığı görülmektedir. Bu bulgular ışığında öğretmen adaylarının oldukça isabetli

| Kastamonu Eğitim Dergisi, 2020, Vol. 28, No. 61 
çözüm önerileri ortaya koyduklarını söylemek mümkündür. Bu durum ise eğitim sistemimiz açısından sevindirici bir gelişme olarak değerlendirilebilir.

\section{ÖNERILER}

Türk eğitim sisteminin sorunları, uzun yıllardır tartışılan ve eğitim sisteminin çevresel değişimlerden etkilenen organik bir sistem olması nedeniyle de tartışılmaya devam edecek olan bir konudur. Eğitim sisteminin önemli bir yapıtaşı olan öğretmen adaylarının bu sorunların farkında olması ve söz konusu sorunlara rasyonel ve etkili çözümler üretebilmesi eğitim sistemimizin çağdaş, bilimsel, birey temelli ve üretken bir çerçevede şekillenmesi bakımından önemli görülmektedir. Bu kapsamda, çalışmada öğretmen adaylarının öğrenci olarak içinde bulundukları ve gelecekte öğretmen olarak işleyişine katkıda bulunacakları eğitim sisteminin sorunlarına yönelik farkındalıkları ve bu sorunlara ilişkin çözüm önerileri incelenmiştir. Öğretmen adaylarının özellikle medyada yer alan eğitim ile ilgili haberler üzerinden sorunları tespit etmeleri istenmiştir. Araştırma sonucunda öğretmen adaylarının eğitim sistemimizin sorunlarına yönelik farkındalığa sahip olduğu ve makul çözüm önerileri sundukları görülmüştür. Ancak gelecekte eğitim sistemimizin farklı sorunlarla karşılaşabileceği ve daha yaratıcı çözüm önerilerine ihtiyaç duyabileceği düşünüldüğünde öğretmen adaylarının bu durum karşısında hazır olmalarının sağlanması gerekmektedir. Dolayısıyla öğretim elemanlarının, öğretmen adaylarını sorgulayan ve yaratıcı problem çözme becerilerini kazanmış öğretmenler olarak yetiştirmeleri gerekmektedir. Öğretmen adaylarına ise alanlarındaki gelişmeleri eleştirel bakış açısıyla takip ederek ve kendilerini entelektüel açıdan geliştirerek eğitim sistemine öğretmen olarak dâhil olma konusunda hazırbulunuşluklarını artırmaları önerilebilir.

\section{KAYNAKÇA}

Abazaoğlu, ì., Yıldırım, O. \& Yıldızhan, Y. (2016). Geçmişten günümüze Türk eğitim sisteminde öğretmen yetiştirme. Uluslararası Türk Eğitim Bilimleri Dergisi, 4(6), 143-160.

Aktepe, V. (2014). Okul yöneticilerinin seçme ve yetiştirme uygulamalarına yönelik öğretmen ve yönetici görüşleri. Turkish Studies - International Periodical For The Languages, Literature and History of Turkish or Turkic, Volume 9/2 Winter, p. 89-105

Arslan, M. (2004). Eğitim sistemimizin kapanmayan yarası-yükseköğretime geçiş. Erciyes Üniversitesi Sosyal Bilimler Enstitüsü Dergisi, 1(16), 3751.

Aytaç, K. (1967). Türkiye'de eğitim sistemi ve eğitim seviyesi. A.Ü.DTCF Felsefe Araştırmaları Enstitüsü Dergisi, 5, $241-254$.

Creswell, J. W., \& Poth, C. N. (2018). Qualitative inquiry and research design: Choosing among five approaches (4th edition). London: Sage.

Çetin, H., Yazar, M.I., Aydın, S. \& Yazıcı, N. (2018). İlköğretim matematik öğretmen adaylarının Türk eğitim sistemi sorunlarına ilişkin görüşleri ve çözüm önerileri. Akdeniz Eğitim Araştırmaları Dergisi, 12(25), 117-135.

Davey, L. (2009). The application of case study evaluations (Çev: Tuba Gökçek). Elementary Education Online, 8(2), 1-3.

Delice, O. E., \& Arslan, M. M. (2018). Koruyucu güvenlik önlemlerine yönelik okul yöneticilerinin ve öğretmenlerin görüşleri. Çağdaş Yönetim Bilimleri Dergisi, 5(1), 54-71.

Erdemli, Ö. (2018). Öğretmene yönelik şiddet medyaya yansıyan olayların incelenmesi. Prof. Dr. Emine Akyüz'e Armağan Akademisyenlikte 50 Yıl (Eds. Karaman Kepenekçi,Y., Taşkın, P.) Ankara: Pegem Akademi.

Erikli, S. (2016). Genç yoksulluğunun temel belirleyicileri: Eğitim ve düzgün iş. Gazi Üniversitesi iktisadi ve Idari Bilimler Fakültesi Dergisi 18(1), 283-302.

Gedikoğlu, T. (2005). Avrupa Birliği sürecinde Türk eğitim sistemi: Sorunlar ve çözüm önerileri. Mersin Üniversitesi Eğitim Fakültesi Dergisi, 1(1), 66-80.

Genç, S. Z. ve Eryaman, M. Y. (2008). Değişen değerler ve yeni eğitim paradigması. Sosyal Bilimler Dergisi. Afyon Kocatepe Üniversitesi, 9(1).

Görgün-Baran, A., Sarıtaş, C. T. ve Şahin-Kütük, B. (2017). Medyada kadına yönelik şiddet haberlerinin içerik ve sunum açısından analizi: Beyazgazete. com örneği. Sosyoloji Konferansları, (55), 107-132.

Güllüpınar, F. (2017). Kamusallığın çöküşü ve bireyin sorumlulaştırılması olarak 'yaşam boyu öğrenme': Eğitim ve istihdam politikalarının eleştirisine bir katkı. Amme Idaresi Dergisi, 50(1), 67-84.

Gündüz, M. (2015). İlk ve orta öğretimde uygulanan şiddet olaylarına öğretmen adayı öğrencilerin anlatılarından bakmak. Marmara Üniversitesi Atatürk Eğitim Fakültesi Eğitim Bilimleri Dergisi, 42, 261-276.

Güngör, G. \& Göksu, A. (2013). Türkiye'de eğitimin finansmanı ve ülkelerarası bir karşılaştırma. Celal Bayar Üniversitesi i.i.B.F. Yönetim ve Ekonomi, 20(1), 59-72.

Hanushek, E. A. \& Wößmann, L. (2007). The role of education quality in economic growth. Policy Research Working Paper 4122, World Bank, Washington, D.C.

Hareket, E., Erdoğan, E. \& Dündar, H. (2016). Türk eğitim sistemine ilişkin bir durum çalışması. Eğitim ve Öğretim Araştırmaları Dergisi, 5(1), 287299.

Houser, J. (2015). Nursing research: Reading, using, and creating evidence. (3rd ed.). Burlington: Jones and Bartlett Learning.

İnan, C. \& Bekler, E. (2014). PISA Sınavlarında Türkiye'nin performansı ve öğretmen eğitiminde çözüm önerileri. Turkish Studies-International Periodical For The Languages, Literature and History of Turkish or Turkic, 9(5), 1097-1118.

Kartal, S. (2013). Öğretmen adaylarının görüşlerine göre eğitim sistemimizde değiştirilmesi gereken noktalar. Uşak Üniversitesi Sosyal Bilimler Dergisi, Özel Sayı, 248-262. DOI: 10.12780/UUSBD185

Korkmaz, M. (2005). Okul yöneticilerinin yetiştirilmesi: Sorunlar-çözümler ve öneriler. G.Ü. Gazi Eğitim Fakültesi Dergisi, 25(3), $237-252$. 
Kutlu-Abu, N., Bacanak, A. \& Gökdere, M. (2016). Öğretmen adaylarının Türk eğitim sisteminin sorunlarına ilişkin görüşlerinin incelenmesi. Amasya Üniversitesi Eğitim Fakültesi Dergisi, 5(1), 287-307.

MEB Strateji Geliştirme Başkanlığı, http://sgb.meb.gov.tr

MEB. (2018). 2017-2018 Milli Eğitim İstatistikleri Örgün Eğitim. http://sgb.meb.gov.tr/meb ivs dosyalar/2018 09/ 06123056 meb istatistikleri orgun egitim 2017 2018.pdf.

Memduhoğlu, H. B. (2007). Türk eğitim sisteminde okulların yönetimi ve okul yöneticilerinin yetiştirilmesi sorunsalı. Milli Eğitim Dergisi, Sayı (176) s. 86-97

Miles, M, B., \& Huberman, A. M. (1994). Qualitative data analysis: An expanded sourcebook. (2 ${ }^{\text {nd }}$ edition). Thousand Oaks, CA: Sage.

Öğülmüş, S. (2006). Okullarda şiddet ve alınabilecek önlemler. Eğitime Bakış, 2(7), 16-24.

Özdemir, F. \& Kaplan, A. (2017). Öğretmen adaylarının bakış açısından Türk eğitim sisteminin sorunları ve bu sorunlara yönelik çözüm önerileri. Electronic Turkish Studies, 12(28), 577-592.

Özdemir, S. (2007). A paradigm shift in early intervention services: From child centeredness to family centeredness. Ankara Üniversitesi Dil ve Tarih Coğrafya Dergisi, 47(2), 13-25.

Özel, E. \& Zelyurt, H. (2016). Anne baba eğitiminin aile çocuk ilişkilerine etkisi. Sosyal Politika Çalışmaları Dergisi, 36, 9-34.

Öztürk, N. (2005). iktisadi kalkınmada eğitimin rolü. Sosyoekonomi, 1(1), 27-44.

Seyfullahoğulları, A. (2010).illköğretim okullarında büyük sınıfların yönetiminde karşılaşılan sınıf içi sorunlara öğretmen yaklaşımı üzerine bir araştırma. Mustafa Kemal Üniversitesi Sosyal Bilimler Enstitüsü Dergisi, 7(14), 21-40.

Sharts-Hopko, N. C. (2002). Assessing rigor in qualitative research. Journal of the Association of Nurses in Aids Care, 13(4), 84-86.

Shenton, A. K. (2004). Strategies for ensuring trustworthiness in qualitative research projects. Education for Information, 22, 63-75.

Şener, G. (2018). Türkiye'de yaşanan eğitim sorunlarına güncel bir bakış. Milli Eğitim, 218, 187-199.

Taşdelen, V. (2012). Eğitimde ezberleme ve anlama. Bilim ve Aklın Aydınlığında Eğitim, 143, 12-17.

Taşdemir, M. (2015). Öğretmen adaylarının Türk mili eğitim sistemi üzerine algıladıkları sorunlar. International Periodical For The Languages, Literature and History of Turkish or Turkic, 7, 881-898. DOI: http://dx.doi.org/10.7827/TurkishStudies.7898

Taşgın, A. \& Sönmez, S. (2013). Öğretmenlik mesleği genel yeterliklerinin sınıf öğretmenleri ve sınıf öğretmeni adaylarının görüşlerine göre değerlendirilmesi. Middle Eastern \& African Journal of Educational Research, 3, 80-90.

Tokuhama-Espinosa, T., Rivera, M., Tobar, C., Solano, I., Proaño, S., Tirira, M. \& Merino, I. (2013). International indicators of quality education: How economic status, units of analysis and culture can influence country choices of key quality indicators in education. Paper presented at the World Education Research Association (WERA) Focal Meeting and 12th National Conference on Educational Research, Guanajato, Mexico, 18-22November, 2013. https://www.slideshare.net/Lascienciasdelaprendizaje/international-indicators-of-quality-educationwera-paper-draft-by-some-authors-november-2013 adresinden alınmıştır.

Uluğ, F. (1998). Eğitim sisteminde değişme yapısal uyum sorunları. Kuram ve Uygulamada Eğitim Yönetimi, 4(14), $153-156$.

UNICEF. (2000). Defining quality in education. Paper presented by UNICEF at the meeting of The International Working Group on Education Florence, Italy. Working Paper Series Education Section Programme Division United Nations Children's Fund New York, NY, USA. http://www.oosci-mena.org/uploads/1/wysiwyg/Quality Education UNICEF 2000.pdf adresinden alınmıştır.

Üstüner, M. (2004). Geçmişten günümüze Türk eğitim sisteminde öğretmen yetiştirme ve günümüz sorunları. İnönü Üniversitesi Eğitim Fakültesi Dergisi, 5(7), 63-82.

Yeşil, R. \& Şahan, E. (2015). Öğretmen adaylarının Türk eğitim sisteminin en önemli sorun, neden ve çözüm yollarına ilişkin algıları. Kırşehir Eğitim Fakültesi Dergisi, 16(3), 123-143.

Yıldırım, A. \& Şimşek, H. (2005). Sosyal bilimlerde nitel araştırma yöntemleri. Ankara: Seçkin.

Yılmaz, K. \& Altınkurt, Y. (2011). Öğretmen adaylarının Türk eğitim sisteminin sorunlarına ilişkin görüşleri. Uluslararası Insan Bilimleri Dergisi, 8(1), 942-973.

Yin, R. (1984). Case study research: design and methods. (3. Basım). London: Sage.

Yurdakul, B. (2008). Yapılandırmacı öğrenme yaklaşımının sosyal bilişsel bağlamda bilgiyi oluşturmaya katkısı. Balıkesir Üniversitesi Sosyal Bilimler Enstitüsü Dergisi, 11, 39-67. 